\title{
Born from below: Urban regeneration through incarnational theological formation in Guatemala City and beyond
}

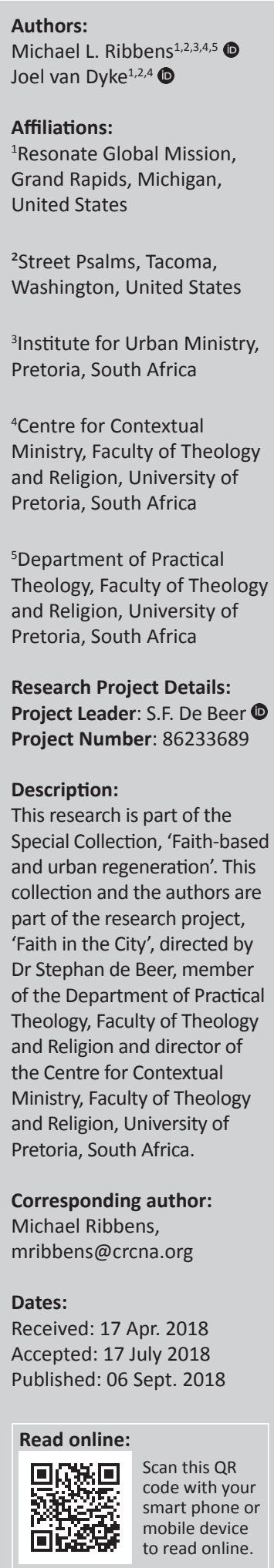

This article sets out to describe the development of and engagement with a global training collaborative around the formation of urban ministry leadership committed to the act of loving cities and working for peace. The collaborative is an initiative of Street Psalms called the Urban Training Collaborative and each urban training hub has agreed to be shaped and formed by an Incarnational Training Framework (ITF). The ITF was constructed over a 20-year period in the midst of a global missional community made up of leaders from cities all over the world. The ITF is infused by an incarnational theology as interpreted from below and focused on the message, method and manner as exemplified in the life and mission of Jesus Christ such that messengers are free of fear and unleashed to love their cities and seek their peace. The Incarnation of Jesus Christ animates faith-based engagement around the complex issues of poverty, injustice, social inequity and violence, and shifts paradigms from scarcity to abundance, theory to practice and rivalry to peacemaking. To shed light on the practical outworking of an incarnational theology from below, we will critically reflect on Guatemala City as a case study to illustrate how the formation of a city-wide missional community was developed through engagement around the aforementioned ITF which led to the corresponding paradigm shifts and then subsequently seeding a global training collaborative

\section{Introduction}

Jesus of Nazareth enters neighbourhoods and animates the Kingdom of God by an embodied message, method and manner of mission. On a particular Sabbath, in a first century Palestinian city, an influential Pharisee invited Jesus for dinner. Luke narrates how Jesus began table conversation with a beautiful question, embraced and thereby also healed someone suffering under excess bodily fluid, and eventually told the parable of the Feast. The neighbourhood watched Jesus with scrutiny as he disarmed the dominant powers of the temple purification system and the Roman colonial enterprise. With all eyes on Jesus, the incoming Kingdom of God was made visible as well as available for people to ponder and even receive as a gift (Nolan 1992:100; van Eck 2013). New Testament scholar Van Eck (2013:12) interprets the parable of the Feast and identifies Jesus as the boundless host who gives 'to those who cannot give back, breaking down physical (walls) and manmade boundaries (purity and pollution) and treating everybody as family (generalised reciprocity), without being afraid of being shamed'. In other words, Jesus took compassion to the fringes of society, to the poor and religiously unclean, all the while nurturing into existence a new and vibrant missional community of disciples and friends. Jesus restored and redefined relationships in the first century and continues to do so today.

We begin our article with the Lukan account because our point of departure is that Jesus' model of mission has much to say about the essence and content of mission and faith-based action in our present and future urban contexts. Jesus exemplified a particular message, method and manner of mission, animating the Kingdom of God (Rocke \& Van Dyke 2017:11). As the boundless host, Jesus, compelled by compassion, the Holy Spirit and the communing Father, releases 'the spiritual technology necessary for human flourishing and shows us how to activate, leverage and steward the power of relationships for the sake of the city', especially with the most vulnerable (Rocke \& Van Dyke 2017:10). Jesus built a new community, a new type of community as Letty Russell (1993:206) articulates, a round-table community, whereby societal barriers and dominant systems are exposed and dismantled so that all could experience the warm love of being at home

How to cite this article: Ribbens, M.L. \& Van Dyke, J., 2018, 'Born from below: Urban regeneration through incarnational theological formation in Guatemala City and beyond', HTS Teologiese Studies/Theological Studies 74(3), a5039. https://doi.org/10.4102/hts. v74i3.5039

Copyright: @ 2018 . The Authors. Licensee: AOSIS. This work is licensed under the Creative Commons Attribution License. 
in God's presence. According to van Eck (2013:13), all the wrong people and sinners, the least of these sisters and brothers, become the legitimate sisters and brothers of Jesus and exercise compassion 'to everybody as God is compassionate towards everybody'.

Such an incarnational vision of mission brought forth in community continues to give shape to an initiative called the Urban Training Collaborative (UTC). The aim of this article is to describe and reflect critically on the UTC as a community of practice for faith-based action and for 'developing incarnational leaders who build just communities of compassion for all, especially the most vulnerable' (Rocke \& Van Dyke 2017:9). Since its impetus, the leadership within the UTC have all committed to being formed and shaped by an incarnational theological framework which was communally constructed and informed by two decades of deep immersion in urban communities, among the least, last and lost. That framework is called the Incarnational Training Framework (ITF). Within our reflections, we attempt to be self-aware and critical to the best of our ability with uncomfortable reflexivity (cf. Pillow 2003) because we were both involved in the formation of the UTC and the ITF, and have biases and blind spots, which we seek to engage in the course of the article. Throughout the article, we are cognisant of the recognition of self and the other and reflexivity as truth and transcendence (cf. Pillow 2003), although we will not systemically label those moments of reflexivity. Even though the ITF was communally constructed and informed by decades of urban ministry engagement, the authors of this article acknowledge that our whiteness and maleness avail privileges that lead to different interpretations, even misinterpretations. We will in no way attempt to give voice to those who already have a voice. Rather, we seek to offer an authentic, albeit personal and messy, interpretation of the development of the UTC and the guiding incarnational theological framework.

We get started by critically reflecting on Guatemala City, Guatemala, as a case study. The interaction with Guatemala City as a case study becomes a backdrop for the article's broader theological engagement. We have no intention of putting this particular narrative of a missional community formed in Guatemala City on a pedestal or prescribing a uniform best practice model. Rather, through the particularity of the theological discourse in one context, it is our hope that others will be able to apply new learnings to their respective cities. The case study begins with immersion and journeying with 'the damned' (Ekblad 2005) of this world to listen to one another and discern pathways and real-world solutions to the intensifying gang violence in Guatemala City. The case study narrates how the incarnational training of leadership formed a city-wide missional community with global ramifications.

\section{Guatemala City: A case study The table as a modus operandi}

Incarnational leaders nurture the relational fabric of the communities and cities they serve, standing in solidarity with the most vulnerable and building bridges with leadership from various sectors - private, public and non-profit (Rocke \& Van Dyke 2017:13). For the sake of analysing the case study of Guatemala City, we want to engage the image of the 'table' (cf. Russell 1993) where leaders of a city are able to connect and build a web of relational networks necessary for urban regeneration. Following Norman Long's actor centred conceptual approach (2001:16-18), one also comes to understand how human agency builds relational fabric and harnesses 'knowledgeability and capability' to make a difference in the current state of affairs. Incarnational leaders are faith-based agents who build relational connections around tables of transformation (cf. Rocke \& Van Dyke 2017:69-70), create room for synergistic collaboration and co-construct solutions with urban communities. From an incarnational perspective as embraced by the UTC, what distinguishes these tables from many others is that they give preferred seating to the vulnerable. They are open tables where all are welcome - literally and figuratively.

The table is the epicentre of all cultures worldwide. The family, society and even faith itself are formed around the table. It is our firm conviction that cities are healed relationally, and thus there is nothing more elemental than table fellowship leading to synergistic partnership. The role of faith leaders in nurturing these tables is significant. In fact, the honourable words for 'ministry', 'minister' or 'to minister' in the New Testament are diakonia [table service], diakonos [table server] and diakoneo [to serve food]. To cultivate what we have come to call 'tables of transformation' (Rocke \& Van Dyke 2017:70), leaders need to master three essential skills of hospitality: table sitting (guests), table setting (hosts) and table serving (waitstaff).

Incarnational leadership begins by learning how and what it means to be a guest - to be invited and to sit at the table of the other. To be a guest is to be fully present and to sit without grasping for power. We are on the turf and terms of those who invite us.

As we sustain the learning posture of being guests at another's table, we can become good hosts who then set tables where all are welcome, especially the most vulnerable. The most vulnerable, those suffering from injustice, poverty, violence and exclusion, according to Russell (1993:197), are the guides for helping us understand 'when justice is done'. Good hosts create a warm and welcoming context for all guests to feel at home.

In the end, incarnational leaders become the diakonos of the city - table waitstaff who serve. The purpose of the waitstaff is to serve the meal in such a way as to enhance the dining experience. Great waitstaff are keenly aware of the entire dining experience, anticipating the desires of the guests and hosts. They move in and out of the meal in a way that is seamless. Their presence is part of the dining experience; but, just like at a great restaurant, the waitstaff are nearly invisible, allowing the full attention of the guests to fall upon the food and the fellowship around the table. 
Incarnational leaders master all three of these relational skills for the sake of the city and often practice them simultaneously. We are always table sitters, setters and servers, never graduating from one role to the next. These elements of the table as a modus operandi avail a helpful structure to unpack the case study around the narrative of the work in Guatemala City.

\section{The table being prepared in Guatemala City}

In 2003, at the invitation of a Guatemalan friend and colleague, Joel Van Dyke (this reference to one of the co-authors is simply to distinguish Joel Van Dyke's integral involvement and lived experience from the other co-author) moved to Guatemala City to participate in a comprehensive vision of training youth workers throughout Central America and the Caribbean. During nearly 2 years of exegeting the city by means of sitting at the tables of the lives and ministries of amazingly gifted youth workers in Guatemala City, it became apparent that the epidemic of gang violence had become an acute, intractable challenge, and demanded focused and targeted attention.

In response to what was learnt at the tables of leadership all over the city, a strategic group of leaders decided to respond through the setting of a collective table to seriously reflect on and engage the chronic violence being caused by warring street gangs on Guatemala City's streets and in her prisons. Seventy-five leaders accepted the invitation to this table shaped in the form of a city consultation entitled, 'Street Psalms'. There was a purposeful commitment to set the table as a consultation as opposed to a conference or congress. The idea of a conference or congress connotes having experts come and pontificate on the causal factors of the issue at hand and suggest policy and practical solutions to and at the problem, flowing from the so-called expertise and experience. Rather than setting a table for experts to come and teach, the choice was made to set a table of consultation for three days of dialogue, appreciative enquiry and collective engagement around the issue at hand.

A key difference to how this particular table was set was the mark of hospitality and welcome by the purposeful inclusion of the voices of gang members themselves. It was decided that there had been plenty of conversation and analysis about gang violence but very little dialogue with gang members themselves - a practice that a commitment to incarnational theology demanded. Thus, the first evening of the three-day consultation was given to active gang members whom were interviewed as a panel by an ex-gang member in front of all of the assembled participants. Questions formulated by the participants were written on 3-by-5 index cards, and facilitators organised the questions into categories and delivered them to the ex-gang member who was moderating the conversation. Upon completion of the panel discussion, all of the consultation participants were divided into smaller groups, each at a table where the 'guest of honour' at each table was an active gang member from the panel discussion as well as several ex-gang members. This was performed to create rich dialogue with gang members as opposed to jumping into conversation about them. Again, a practice engaged because of a firm commitment to incarnational theology.

In addition to the real-time conversations at the consultation outlined above was the distribution of a document prepared by incarcerated gang members whose voices obviously were not able to be present at the active dialogue because of their incarceration. The incarcerated gang members prepared a 12-page document to be distributed among the participants of the consultation. The principle here was to give priority seating to the marginalised and in this case primacy of voice to those whose voices were rarely directly heard at tables that had been set in the city around the issue at hand.

Upon conclusion of the three-day consultation, the national director of prisons in Guatemala (who had attended portions of the consultation along with the Guatemalan national director of police) extended an invitation to the team who had set the table of the consultation to consider the development of a gang chaplaincy initiative. The idea of the chaplaincy initiative was to create a means by which ex-gang members whose lives had been holistically rehabilitated, to visit incarcerated gang members on a weekly basis for the purpose of relationship-building, advocacy work and Bible study, only by the invitation of those who were incarcerated (Van Dyke 2008).

As part of a successful grant proposal to launch a one-year pilot project around the idea of a gang chaplaincy initiative, we began holding monthly training events for the exgang members, now turned chaplains, around a series of conversations (theological intensives) that came to be known later as the Street Psalms Intensives. They, in turn, invited friends from around the city who were working with gangs and other marginalised groups, such as street kids, women in the midst of domestic violence and sex workers, far outside the scope of incarnational engagement of the established church community.

What emerged was a robust group of 50-60 grass roots leaders who began meeting every month for an entire day, being shaped and formed by the Street Psalms Intensives. In effect, over the course of 3 years, the Street Psalms Intensives served as a series of courses that have since been facilitated with more than 3000 leaders in 26 cities and 14 countries. They were conversations rooted in an incarnational theology from below with a profound commitment towards learning how to see and celebrate good news in hard places. These conversations led to a vivid transformation of the way the gang chaplains and their colleagues learnt to love their city and seek its peace and the result was the formation of a vibrant missional community.

The intensives were designed for the gang chaplains and their invited friends who were eager to experience the transforming power of the Incarnation in the face of Guatemala City's 
greatest challenges. They were rich conversations more interested in questions than answers and dialogue than doctrine. The style was more jazz than classical, more poetic than prosaic and more playful than dogmatic. There was a clear commitment to engage the head, heart and hands of the urban leaders of Guatemala City in a joy-filled, risky dialogue that called forth a freedom from fear and an invitation to love Guatemala City into greatness. That said, participants were engaged and challenged by a gospel of peace that leads to freedom from a kind of violence that would otherwise hold leaders captive in isolation and rivalry, calling forth a new humanity in Christ.

The missional community in Guatemala City committed to gathering around a table of transformation for three years. The table was set around life-giving, practical incarnational theological training that was organically emerging and simultaneously being field tested in other locations around the world. The names and brief descriptions of the Street Psalms theological intensives that shaped the extended dialogue in Guatemala City are as follows:

- Born From Below: Mystery of Word-Made Flesh (Christology/Anthropology)

Coming face to face with Word-made flesh while discovering what it means to be human and the God who makes us human.

\section{- Scandal of God: Undergoing Atonement (Soteriology)}

Undergoing the scandal of the cross and the cruciform shape of mission.

- In But Not Of: Understanding the Grammar of God (Pneumatology)

Celebrating the unbounded Spirit of Jesus and the implications for mission.

- It's a Family Affair: Redeeming Our Inheritance (Ecclesiology)

Inhabiting the complex world of the Biblical family and what the family of God means for mission.

- The City of Joy: Welcome to God's Playground (Eschatology)

Celebrating the city as God's playground of grace for all people and how the New Jerusalem enters Babylon.

- Making Peace with God: Transforming Mission in a Violent World (Ethics)

Practicing the gospel of peace in the context of violence and undergoing mercy that transforms the world.

The missional community of Guatemala City leaders who participated in the monthly training sessions also spent time visiting each other's ministries and homes in between the monthly training. In addition, those facilitating the monthly conversations were committed to visiting the ministries, communities and prisons of all participants in the missional community. The relational fabric strengthened. Fellowship events ensued, resources between ministries were being shared and collaborative initiatives and joint fund-raising efforts were kindled. All of these faith-based actions and initiatives occurred as a result of having sat together around a collective table where incarnational theological training and formation was on the menu.

Upon completion of the six courses in the series of Street Psalms Intensives, there was an active search for a viable organisational home that could continue to support and nurture the extensive group of grass roots leaders in Guatemala City who had formed into a missional community. When no organisation was located in Guatemala City that had a mission or vision aligned with the engagement and support of such a missional community of grass roots leaders, the decision was made to incorporate the Center for Transforming Mission (CTM) in Guatemala City to fulfil that gap.

While the missional community in Guatemala City was being formed and shaped around the table of incarnational theological training, missional communities of grass roots leaders began to form around similar tables with conversations nurtured in their respective contexts. These cities included (among others): Santo Domingo, Dominican Republic; Portau-Prince, Haiti; Nairobi, Kenya; Seattle-Tacoma, Washington; Philadelphia, Pennsylvania; and five different cities in Nicaragua. To shed light on what was happening concurrently and at a global level, we now turn to providing a brief historical perspective on the development of a global UTC.

\section{Development of a global Urban Training Collaborative}

We acknowledge that when one considers the historical development and journey of a pioneering initiative, the fits and starts and gradual build-up make it difficult to line up all the details. Even though we were both involved organisationally and personally, we will not attempt to give an exhaustive account of the history of the collaborative but rather highlight the most significant elements. The three threads running through the history of the UTC are evident in the naming itself - urban, training, collaborative.

The urban sidewalks, street corners and back alleys of Philadelphia in 1996 grounded the theological engagement for a circle of friends journeying with and training urban youth workers. This training initiative called Philadelphia Project for Youth Ministry was supported by the Pew Charitable Trust and jointly managed by Kingdomworks and the Center for Urban Resources with Joel Van Dyke as the Director (Street Psalms 2016). The initiative gained traction in Philadelphia and eventually incorporated as an organisation known as Making Urban Disciples (MUD) Inc., in 1999, with Kris Rocke serving as Executive Director. Eventually, because of a lack of financial base, MUD Inc. lied dormant for a few years until an invitation from World Vision to become a training partner for its Vision Youth initiative with urban youth outreach workers in nine US cities (Street Psalms 2016).

Upon accepting the World Vision invitation, MUD Inc. was renamed CTM and then scaled its training to global levels in 2005, beginning with the Street Psalms Gang Consultation in 
Guatemala City referred to above. Over a period of eight years, CTM 'trained more than 3000 people in 26 cities and 14 countries' (Street Psalms 2016). Furthermore, staying true to the thread of collaboration, CTM strengthened organisational strategic partnerships to establish ongoing presence and programme offices in Guatemala City, Santo Domingo and Nairobi (Street Psalms 2016). One such strategic partnership was Resonate Global Mission (formerly Christian Reformed World Missions) which committed to the implementation of a Strategy of Transformation Initiative in Central America and the Caribbean in 2006 led by Joel Van Dyke who had already been living in Guatemala City per the invitation from Guatemalans since 2003. Another strategic partnership emerged between CTM and Leadership Foundations in July of 2011. Thus, in 2011, the three partners of the UTC were beginning to engage each other in different contexts and by extending and accepting one another's invitations to learn from each other and build relational capital. Relationships were being activated, leveraged and stewarded for the sake of the city, especially the most vulnerable (cf. Rocke \& Van Dyke 2017).

This was indicative of the relationship between Resonate Global Mission and Leadership Foundations in 2012. Resonate hosted a 'Transformational Networks Consultation' in Managua, Nicaragua 11-13 September 2012, and gathered staff from cities around the world, existing and potential partners to consider the vision and transformational development work of the Nehemiah Center in León, the second largest city of Nicaragua. The Senior Vice President of Leadership Foundations, H. Spees, participated in the consultation and took copious notes. In the notes from Spees (2012), one uncovers again the genetic material of the UTC, namely training and the focused intention to collaborate, both locally and globally. Daniel Boniche of the Nehemiah Center stated it succinctly: 'We provide training and relationships' (Spees 2012:8). Additionally, the consultation commenced with prayer for the action plans that were collectively identified:

North/South Relationships, [Training] Tool Box Plus, Established network group - a vision for a network of networks, Beginning network groups, Sustaining our connections...initiate a community of practices ... invite others into the conversation i.e. women, minorities, other voices and voices of dissent. (Spees p. 45)

Even though there was no mention in the action plans of a deliberate focus on urban contexts, one finds again the essence of the emerging concept for a global training collaborative.

In June of 2013, as the work of training developed in different cities around the world, the work of the CTM decentralised and developed into four independent organisations: CTM Resource Center located in Tacoma, CTM Kenya, CMT (Centro para la Misión Transformadora) Dominican Republic and CMT Guatemala. In an effort to align with the evolving vision and shifting responsibilities, the CTM Resource Center officially became Street Psalms in
2014 to better function as 'a training center serving global partners such as Leadership Foundations and Resonate Global Mission' (Street Psalms 2016).

In April 2014, Leadership Foundations hosted a planning and training summit in Memphis, Tennessee with 17 leaders from across the intercontinental networks of Leadership Foundations, Street Psalms and Resonate Global Mission. The gathering set out to discern and shape a working concept paper which articulated the vision for the UTC and offered recommendations for partnership responsibilities within the collaborative. The concept paper, revised on 15 April 2014, states the shared vision drawn from Jesus' first public address in Luke 4 which speaks about good news and liberation of the poor:

We envision a dynamic global training collaborative that equips the head (Reflection), heart (Discernment) and hands (Action) of urban community leaders and organisations who seek the social and spiritual renewal of cities. (UTC 2014:1)

The concept paper further articulates the core theological perspectives which centre the content, pedagogy and community practice of the UTC (2014):

Abundance: An asset-based vision of life that begins with God's yes, rooted in the assumption, there is enough - enough of all the ingredients for human flourishing in every context. The central task is to pay attention to how the Spirit is actively at work in cities and joyfully participate in unleashing forces for good.

From Below: An incarnational vision that begins with the reality of what IS. Special attentiveness is given to the lived experiences and unique perspectives of those on the margins of society - as they illuminate a way forward for all of us together.

Peacemaking: A vision of civil society rooted in the biblical vision of shalom. Accentuated is the practice of unplugging from the violence of rivalry and exclusion, instead modeling ways of being in which enemies are embraced as friends and all parties are mutually transformed. (p. 2)

Throughout the rest of the article, we attempt to reflect critically on these core theological perspectives, beginning with the notion from below. We will then explore the generative influence of an incarnational theology from below to shift paradigms from scarcity to abundance, theory to practice and rivalry to peacemaking.

\section{An incarnational theology as interpreted from below}

It is important to note that we are expressing an incarnational theology, certainly not the incarnational theology, as if we cornered the single, definitive version. An incarnational theology nevertheless still is a particular theology because of one's chosen interlocutors and locus of reflection. New Testament scholar, Ben Witherington III, encourages his readers to really listen to the Word of God afresh by engaging seriously the historical reality of the text itself and the author's intentions and rhetorical devices: 'a text without a context is just a pretext for what we want it to mean' (2015:74). Witherington (2015) guides his readers to reconsider how to 
be proficient hearers of the spoken Word because the Word of God was intended to be auditory experience in a community, within a particular social, historical, cultural and rhetorical context. We acknowledge Witherington's caution of anachronism, and yet for us, our theological conversation and faith-based engagement also has to take seriously and give careful consideration to our contemporary contexts. Here, we try to apply Witherington's statement, 'a text without a context is just a pretext', by taking an urban turn to theological discourse. 'For us, the text is the incarnate Word of God. The context is the city that gives shape to God's Word' (Rocke \& Van Dyke 2017:19). So, while we agree with Witherington on the necessity for historical contextual readings of the Bible, we also encourage an active mode of doing theology in community, exegeting the Bible from our present context, which for the foreseeable future is urban. An urban context that is uniquely complex, precarious and vulnerable, while also pregnant with potential and opportunity.

\section{City context from below}

Unfolding around us in our neighbourhoods is the largest human migration in history. The world is urban and every day urban growth continues to swell, with projections showing that more than $70 \%$ of the world's population will live in cities by 2050 (Saunders 2010:22). The United Nations' (UNFPA 2007; UN-HABITAT 2003) forecasts indicate that by the year $2030,80 \%$ of the world's urban population will be in Africa, Asia, Latin America and the Caribbean where, currently, 1 billion people live in informal and slum-like conditions.

Mike Davis' Planet of Slums (2007:121-150) names the vulnerabilities within the toxic ecology of the present-day urban planet - hazardous geology, surplus of industrial and human waste, anarchic traffic, looming infernos, little to no potable water and living incubators for diseases. Death, disaster, decay and deception are literally all around. Doug Saunders (2010) seeks to neither romanticise nor misrepresent this reality and so coins 'arrival city' as the dynamic and precarious new urban world, with possibilities for cultural rebirths, new economies or drastic deathblows, like never experienced before. Paul Collier in The Bottom Billion challenged his readers to consider: 'Change in the societies at the very bottom must come predominantly from within; we cannot impose it on them' (2007:xi [italics added]). Collier's book is not specifically about the urban transition or the 'arrival city', and yet, the trappings of chronic conflict, mismanaged resources, aggravated costs, disconnection and bad governance could turn the bottom billion slum-dwellers into two billion if change is not pursued gregariously from within and from below (Collier 2007:17-75; Lall, Henderson \& Venables 2017; UN-HABITAT 2003).

Our spirituality and theological grounding necessitates a commitment to journey alongside and in solidarity from within the bottom billion. We stated earlier that the city is the context that gives shape to God's Word. The incarnational theology we continue to try to understand and practice is a theology as interpreted from below. Such an incarnational theology infuses the UTC and fuels the prophetic imagination to cultivate cities as robust places of flourishing for all people, especially the most vulnerable (Rocke \& Van Dyke 2017:9).

\section{Theological approach from below}

With the given urban realities of one or two billion people at the 'bottom', our way of doing theology has to be particularly situated within urban contexts. Recall the saying: a text without a context is just a pretext. For Vellem (2014:6), it is irrelevant pretext if theological study and pursuit of knowledge does not seriously consider today's urban situations and everyday life of urban inhabitants. The bottom billion shack-dwellers are the legitimate interlocutors for robust urban theological study and the shack is the primary locus of theological reflection (Vellem 2014:6); among and from within the bottom billion or two. Furthermore, this hermeneutical and epistemological priority arises from below, from within the conditions, experiences and stories of the poor and urban suffering (Kritzinger 2014:5). The possibility for liberating understandings and actions can only occur when the contextual approach to doing theology is from below.

This has been true of our walking, working and writing in the city, devoted to listening to the particular perspectives of the poor and committed to overcoming our suffering together. The people and places interpreting us, specifically exposing our facade of self-sufficiency and giving shape to our formation and theological questions, have been within the red-lined, divested southeast side of Grand Rapids, Michigan, handmade shacks of the slums in Nairobi, the streets of Philadelphia and the prisons, dump sites and cemeteries of Guatemala City. From below, it indicates intentional invitation and careful attention to specific, often forgotten and contested places, diverse voices, strategic interventions, real-world struggles and solutions and empowered experiences (De Beer 2014). The least, last and lost have dignity, sources of wisdom and resourceful interventions worthy of attention. With this in mind, we circle back to the beautiful question (Rocke \& Van Dyke 2017): 'God, who are you and who are we?' In a generative way, we now consider the Incarnation (Word became flesh) to further shape and fill-in our urban theological discourse. Jesus took upon himself vulnerable human nature, choosing to place his feet into 'naked humanity' (Rohr 2004).

\section{Jesus took upon himself vulnerable human nature}

The Incarnation is a scandalous reality and often an immediate affront. Historically, Gnosticism operated like a parasite to contort understandings and suck vigour from within the youthful Christian faith (von Balthasar 1990:1). It would take a certain level of shrewdness and creative nuance to deal with the parasitic nature of gnostic perspectives. King (2003:2), in her book What is Gnosticism?, asserts that 'Gnosticism has been constructed largely as the heretical other in relation to diverse and fluctuating understandings 
of orthodox Christianity'. As such, we are not adhering to the idea that Gnosticism was a static reality as an identifiable religion unto itself but simply trying to show how many of the belief systems identified as 'Gnostic' were offset against orthodox Christianity and gave prominence to perspectives from above over perspectives from below. A dualistic mind, essentially binary thinking, built and sustained gnostic categories of thinking. The either/or perception of what is really real emphasised the excellence of the mind, higher spiritual knowledge and superiority of the soul-spirit. These would be over, above and even against the body, the earthy and the material world. Such dualistic thinking eventually leads to a belief in two Christ's, a street-level Christ and an out-of-this-world Christ.

An early urban church leader, Irenaeus of the city of Lyon, clearly understood that such dualistic thinking is radically anti-Christian and could corrode life within the faith community from the inside out. The ideologies and practices of gnostic thinking needed to be debunked by a robust life-giving understanding of God, the church, Scripture and the Word-made flesh. With keen insight, Irenaeus articulated 'that God "takes a hand" directly in the world' (Norris 1980:11). How earthy and vulnerable! By reflecting on the Word as the servant 'hand' of God, Irenaeus portrayed Jesus as the way in which God is present in and with the world (Norris 1980:11). The same hand soiled in creation is the hand bloodied on the cross, and the wounded resurrection hand that gave thanks, broke open bread and shared.

The Incarnation is God's grit to a world troubled by the momentum of sin. Riddled with an individual and collective disposition to disobey, our inclination is to run and hide in shame, judgement and secrecy all the while acting as if we have been forgotten and alienated. However, the 'hand' of God searches for us, calls us forth and even woos us. Jesus as the 'hand' of God, according to Irenaeus, 'became the dispenser of His Father's grace...showing God to [humanity], presenting [human beings] to God' (von Balthasar 1990:44). Within the UTC, we lyrically state, 'the Incarnation is love with skin on it' (Rocke \& Van Dyke 2017:31). This has always been God's first plan of action and pattern of creation. 'It is God's "yes" to a world that has forgotten its belovedness' (Rocke \& Van Dyke 2017:31). Jesus took to himself vulnerable human nature in the form of a servant and 'sets the stage for the transformation of humanity by the work of the Holy Spirit - the process of redemption' (Norris 1980:11-12).

This early development in Christian thinking nurtured into reality a sincere commitment to direct engagement with the city (cf. Louth 1989:139-151). By understanding Jesus as the way in which God is present in and with the world, the early Jesus-followers developed actions and attitudes that were certainly distinct, not of this world while simultaneously avoiding the temptation of adopting attitudes of escapism. We read in The Epistle to Diognetus, 'As the soul is diffused through every part of the body, so are Christians through all the cities of the world ... but they are not part of the world' (Louth 1989:145). Imagine followers of Jesus in a time of vulnerability, under threat and confronted with colonial oppression, still faith-rooted and committed to compassion, community and holistic engagement with all elements of city life. Cities are transformed the way they are created, relationally.

Jesus' faithful work to enter our tenuous situation and the early church's faith-based response are breathtakingly inspirational. As we turn now to consider how and where Jesus chose to stand, we find ourselves again faced with the reality that text, Incarnation and the urban context continue to interpret us.

\section{Jesus chooses a place to stand}

The prolific writer and creative apologist, C.S. Lewis, wrote two books specifically on the shared human problem of pain, loss, suffering and death. The first he wrote very much from the head, whereas the second, A Grief Observed, spilled from Lewis' wounded heart. Lewis (1961) writes as cancer steals away his beloved wife:

My idea of God is not a divine idea. It has to be shattered time after time. He shatters it Himself. $\mathrm{He}$ is the great iconoclast. Could we not almost say that this shattering is one of the marks of His presence? The Incarnation is the supreme example; it leaves all previous ideas of the Messiah in ruins. (p. 66)

Our consideration of another facet of the Incarnation begins with Lewis' tragic, yet deep reflection of Jesus taking a place to stand because it points out a blind spot within our Western theological assumptions. Our tendency towards triumphalistic ways of engagement continues to be shattered as we develop the hermeneutical impulse from below. The intentionality of Jesus to choose a particular place to stand, with naked humanity, is significant in profound ways.

The Incarnation is Word-made flesh, but it is also about God taking place (Bergmann 2008). The UTC is centred by the message, method and manner as modelled in the life and ministry of Jesus - a particular way of seeing, doing and being. This is at the heart and soul of the ITF which all UTC Training Hubs have agreed to be shaped and formed by. Underpinning this understanding is the intuitive notion that individuals, communities and cities experience occasions of healing and signs of transformation through relationships, in love (Rocke \& Van Dyke 2017:11). And yet, as a collaborative, we have not given much consideration to the reality that space is also relational and can be life-giving or lifethreatening. How might Jesus' particular placement expose spatial injustices and at the same time open possibilities for sustaining spatial justice?

Soja (2003:275), an urbanist and mentee of Henri Lefebvre, surfaced the concept of a spatial turn, highlighting the reality that 'all social relations remain abstract and unrealised until they are concretely expressed and materially and symbolically inscribed in lived space'. Soja reminds us that we are temporal, social and spatial beings. This spatial turn provides vital insight for the UTC. We see relationships of love as the 
driving force for change in the city. By taking into account Soja's perspective, healing and transformation can only be realised and concretised within lived space; otherwise, it remains an abstract whim.

We are cognisant that the reverse is also true. Relationships can be manipulated and become complicit with forces of collusion and corrosion. Socio-economic and political activity can construct and distort space to violently perpetuate urban suffering and spatial injustice. De Beer (2016:2) calls 'for a spatial justice agenda, concretised in local space and place, where liberation needs to be worked out concretely in deliberate, creative or subversive resistance to death-dealing forces'. So as an urban collaborative infused with an incarnational theology, if we are deliberately committed to seeking the peace of our cities in the fullness of relationships, we would be amiss to not consider the relational abuses, violence and suffering as experienced from below and concretised in space. Where is our place to stand? The locus of reflection or the particularity of our place matters. We ought to heed the input from Bergmann (2008:83) 'to reflect on urban injustice and the significance of urban suffering as a place of encounter between the life-giving Spirit and Liberator and the inhabitants of city space'.

With the spatial turn in mind, we now consider how and where Jesus was placed and its practical implications of an incarnational theology from below. South African theologian, Cochrane (1994:12), reflected on the discourse of Christ above at the right side of God's throne in heaven and Jesus below, 'emphasising not substance but process, not essence but direction'. Jesus of Nazareth 'became an outcast by choice' (Nolan 1992:34 [italics original]). As was mentioned in the introduction of the article, Jesus as the boundless host was moved with compassion towards the city, the poor, prisoners, blind, oppressed and enslaved. That downward process and direction of Christ above and Jesus below shapes, orients and colours all other place claims. For Cochrane's lived experience, the direction was a downward mobility to be among the shack-dwellers and within the so-called informality of Amawoti, outside Durban, to listen to the knowledge and faith practices of base community Christians (1994:12). Again, Cochrane provides us with clarifying perspective (1994):

The significant fact about Jesus is that he is actively present in addressing these matters [oppression, Bantu education, violence, poverty, political imprisonment], he is where the people are, he is down below on their piece of earth. (p. 9, [italics original])

Another South African theologian, Klippies Kritzinger (2014), speaks of Jesus identifying:

himself with their plight; he is, in a special sense, the helper of the helpless. And in this he reveals to us who God is: the One who stands by the side of those who suffer unjustly. (p. 5)

According to Rocke and Van Dyke (2017), there is a 'geography to grace' because in the end:

the Incarnation reveals that grace really is like water - it flows downhill and pools up in the lowest places. That's where we see
God and ourselves most clearly! That's where we become fully human and where the hope of the world dwells. If our cities are to bear the marks of holistic transformation the process will need to happen from the bottom up and the inside out. That's the Incarnation. (p. 40)

After giving careful and critical consideration to the core theological perspective from below, we now turn our focus on how such an incarnational theology has been shifting paradigms from scarcity to abundance, theory to practice, and rivalry to peacemaking.

\section{Jesus' message, method and manner shifts paradigms}

\section{From scarcity to abundance}

The message of Jesus was shaped by a particular way of seeing. We are interested here in cultivating a shared perspective that is shaped by the Incarnation and transforms the way we see our cities. In the preface of his book, And Now I See: A Theology of Transformation, Barron (1998) summarises it well:

Christianity is, above all, a way of seeing. Everything else in Christian life flows from and circles around the transformation of vision. Christians see differently, and that is why their prayer, their worship, their action, their whole way of being in the world have a distinctive accent and flavour. (p. 1, [italics original])

Hauerwas (1974) makes an equally bold claim:

we can only act in the world we see, a seeing partially determined by the kind of beings we have become through the stories we have learned and embodied in our life plan. (p. 69)

Within the relational fabric of the UTC, we have come to witness people who can see, touch, hear and even smell love and hope in the most unexpected places. If this is true, and we think it is, the most urgent task of urban leadership is learning how to see. In the documentary film, Reparando (2010), Tita Evertz sits on the edge of the largest slum community in Central America, La Limonada, and makes a profound statement. As she gazes upon the sea of concrete, tentacles of illegally strewn together electrical wires and a river of raw sewage, she makes the scandalous statement, 'I sit here looking over La Limonada and all I smell is hope' (Reparando 2010). Tita has Easter eyes; while others see death and desperation she looks through the hope-filled and faithfilled lens of the resurrection. Like Tita, we want to see our cities and our most vulnerable neighbours through the eyes of the resurrected Jesus. This is our 'distinctive accent and flavor'. Seeing through the eyes of Jesus gives us an assetbased vision of life that begins with God's 'yes', thereby abiding in the assumption that there is enough - enough of all the ingredients necessary for human flourishing in every context.

When we see our cities through the eyes of Jesus, we can see them as living, breathing organisms filled with the lifegiving, empowering presence of God's Spirit. Because of this, we pay attention to how the Holy Spirit is already at work in 
cities and joyfully join the Spirit in unleashing forces for good. Walter Brueggemann (1999) calls out this tectonic shift in perspective when he advocates for a movement out of the myth of scarcity into, instead, a liturgy of abundance.

When seen this way, we do not bring the gospel anywhere. Rather, we bear witness to the gospel at work everywhere. The city is a burning bush ablaze with God's presence. We are called out of the myth of scarcity into a world view of God's abundance. This is Jesus' peculiar way of seeing.

\section{Theory to practice}

Jesus' method was shaped by a particular way of doing. We are interested here in cultivating a shared practice that is shaped by the Incarnation.

Media analyst and communication expert, Marshall McLuhan, coined the phrase, 'The medium is the message' (1964:7-23). Historian Hayden White, it would seem at first glance, offered a different perspective than McLuhan. In The Content of the Form, White (1987:27) contends that the form of the discourse 'adds nothing to the content of the representation'. One might presume then that the medium (form) actually does not influence the message (content). Later in the same chapter, White adds necessary clarity which ultimately supports McLuhan's perspective. White (1987:42) posits, 'to change the form of the discourse might not be to change the information ... but it would certainly change the meaning produced by it'. The very medium we choose for our communication has social, psychological and spiritual consequences and produces different meanings (McLuhan 1964:8; White 1987:42). The way we communicate something is what is actually communicated. In other words, how we communicate is what we communicate. For example, if the words 'I love you' are shouted angrily, the person who hears 'I love you' actually experiences 'I am angry with you', or quite possibly even 'I hate you'. The medium is the message.

God's medium is also God's message for us: God comes to us in the flesh through Jesus, the most complete revelation of God. But God also comes to us in the flesh through those in whom we least expect to see God. We are not saved by ideas or theology or doctrine. We are saved in and through relationship, because reality is relational. Sadly, much of Western Christianity for the last 500 years has located faith from the neck up, or what Father Rohr calls the 'control tower' (2011). We feel compelled to get our ideas right and then go about the business of enacting them. Our addiction to 'theory first, practice second' is dangerous, as we have already noted. The demonstration of one's faith is by one's life. That is why the most fruitful approaches to city transformation call people from theory (above) into incarnational practice (below), as modelled for us in the life of Jesus.

\section{Rivalry to peacemaking}

Jesus' manner was shaped by a particular way of being. We are interested here in cultivating a shared manner, a way of being in community that is shaped by the Incarnation. How do we embody the message and method of Jesus?

The final vision in Scripture is the New Jerusalem which 'represents the true fulfilment of the ideal of the city, a city truly worth belonging to' (Bauckham 1993:130). The New Jerusalem is the city of peace. The Hebrew word for peace is shalom, a richly textured word that is not easily translated into English. Neal Plantinga captures the fullness and intention of shalom; it 'means universal flourishing, wholeness, and delight, in which natural needs are satisfied, natural gifts fruitfully employed ... it is the way things ought to be' (1993:182). It is where justice and righteousness meet. It is the place of human flourishing. Shalom is a divine break-in. It is what happens when heaven breaks into the human condition and becomes visible. Shalom is our deepest intuition and it is our deepest desire (Rocke \& Van Dyke 2017:76).

Incarnational leaders work for a vision of civil society rooted in the biblical vision of shalom. We practice unplugging from the violence of rivalry and exclusion, modelling ways of being in community in which enemies are embraced as friends. The journey of foes becoming friends is mutually transformative.

The call of the Incarnation is to become the community we wish to see. Jesus said, 'Blessed are the peacemakers for they shall be called children of God' (Mt 5:9). Peace is the rhythm of God's family. To be a peacemaker is to be a child of God. One could say that peace has often been the goal, but it has not always been the manner in which we have pursued the goal. Jesus makes it clear that is it is not enough to have a good goal. The way in which we seek our goal is the goal we seek. We must embody the peace we seek if it is peace we expect to find.

\section{Conclusion}

\section{Practical outworking of the Incarnational Training Framework: Urban Peacemaker Fellowship}

After several years of encouraging grass roots theological development and leadership formation in cities throughout the global UTC, we began to wonder how we might co-create an initiative that remained incarnationally faithful to the unique context of each city while at the same time engaging together in a formation process in a unified manner. We wanted to avoid becoming overly prescriptive, such as establishing a universal curriculum, and yet our desire was to have something concrete enough in each city to give shape as a collective and network. We circled back therefore to the modus operandi of the table. What might happen when inspired leaders gathered to engage a targeted, missional question that challenges their city? How might a table of transformation on a missional question foster friendship, joint initiatives and authentic action? This is the purpose of the Urban Peacemaker Fellowship (UPF) - to engage difficult questions in a way that translates vision into action and yields real results. 
Eight cohorts began in January 2018 as a UPF pilot project and contextually developed missional questions around which cross-sector leaders sustain dialogue. The questions that are operative in this first pilot year of the UPF are the following (Street Psalms 2018):

'How can/should the people of faith in Anchorage respond to the violence in our city?' (Anchorage, Alaska)

'How does an informal, diverse group of community leaders become a sustainable organisational framework in the midst of a racially divisive city?' (Grand Rapids, Michigan)

'How can we work together to develop new narratives for peacebuilding that heal the collective woundedness of Guatemala City?' (Guatemala City, Guatemala)

'How can we [as faith leaders in Managua] be better-equipped and respond more effectively to the epidemic of family disintegration in our city?' (Managua, Nicaragua)

'How can we equip grassroots leaders who serve the informal settlements of Nairobi with an incarnational theology of peace?' (Nairobi, Kenya)

'How do we develop leaders in vulnerable communities, who are recipients of services provided by our outreach, in a way that is mutually transformational?' (Salem, Oregon)

'How can a group of pastors collaborate to help each other and their congregations practice peace?' (Tacoma, Washington)

'How does Street Psalms [board, staff, senior fellows] reflect the gifts and diversity of the cities we are called to serve, with specific focus on gender equity throughout the network?' (Tacoma, Washington [Street Psalms])

Strategic, cross-sector leaders from each city gather together around their particular missional question. Careful attention was given to attempt to assure that each question was contextual, action-oriented, time-sensitive and intended to initiate creative incarnational action. The core outcome of the UPF is rooted in the development of incarnational leaders who love their cities and seek their peace. Success is measured around the three paradigm shifts of the ITF listed above that serve as metrics for incarnational leadership. Throughout the year-long formation process, each fellowship records their conversation in the form of a case study meant to engage their respective urban communities, eventually creating an impact artefact that codifies the wisdom and understanding so that it can be effectively shared with the rest of the global UTC and elsewhere as invited. We are only at the inception of the first year of the pilot project, with eight fellowships engaging missional questions that emerged directly from the particularities of each city context. Shaped and formed by the ITF, the UPF initiative is meant to result in faith-based action and creative solutions to real-world urban problems.

\section{Acknowledgements Competing interests}

The author declares that he has no financial or personal relationships which may have inappropriately influenced him in writing this article.

\section{Authors' contribution}

M.L.R. and J.V.D. contributed equally to the conceptualisation and writing of the article.

\section{References}

Barron, R., 1998, And now I see: A theology of transformation, Crossroad Publishing Company, New York.

Bauckham, R., 1993, The theology of the book of Revelation, Cambridge University Press, Cambridge, UK.

Bergmann, S., 2008, 'Making oneself at home in environments of urban amnesia: Religion and geology in city space', International Journal of Public Theology 2, 70-97. https://doi.org/10.1163/156973208X256457

Brueggemann, W., 1999, 'The liturgy of abundance, the myth of scarcity', Christian Century March 24-31, pp. 342-347.

Cochrane, J.R., 1994, 'Christ from above, Jesus from below', Journal of Theology for Southern Africa 88, 3-14.

Collier, P., 2007, The bottom billion: Why the poorest countries are failing and what can be done about it, Oxford University Press, New York.

Davis, M., 2007, Planet of slums, Verso, London.

De Beer, S., 2014, 'Whose knowledges shape our city? Advancing a community-based urban praxis', De Jure 47(2), viewed 29 April 2017, from http://repository.up.ac.za/ bitstream/handle/2263/43798/DeBeer_Whose_2014.pdf?sequence $=1 \&$ is Allowed =y

De Beer, S., 2016, 'Discerning a theological agenda for spatial justice in South Africa: An imperative for sustained reconciliation', HTS Teologiese Studies/Theological Studies 72(1), a3566. https://doi.org/10.4102/hts.v72i1.3566

Ekblad, B., 2005, Reading the Bible with the damned, Westminster John Knox Press, Louisville, KY.

Hauerwas, S., 1974, Vision and virtue: Essays in Christian ethical reflection, Fides/ Claretian, Notre Dame, IN.

King, K., 2003, What is Gnosticism? Belknap Press of Harvard University Press, Cambridge, MA.

Kritzinger, J.N.J., 2014, 'Concrete spirituality', HTS Teologiese Studies/Theological Studies 70(3), Art. \#2782, 12 pages. https://doi.org/10.4102/hts.v70i3.2782

Lall, S.V., Henderson, J.V. \& Venables, A.J., 2017, Africa's cities: Opening doors to the world, World Bank, Washington, DC, viewed 11 February 2017, from http://www. worldbank.org/en/region/afr/publication/africa-cities-opening-doors-world

Lewis, C.S., 1961, Grief observed, 1994, HarperCollins Publishers, New York.

Long, N., 2001, Development sociology: Actor perspectives, Routledge, London, New York.

Louth, A. (ed.), 1989, Early Christian writings: The apostolic fathers, Penguin Books, London.

McLuhan, M., 1964, Understanding media: The extensions of man, Routledge Classics, London, New York.

Nolan, A., 1992, Jesus before Christianity, Orbis Books, Maryknoll, NY.

Norris, Jr., R.A. (ed.), 1980, The Christological controversy, Fortress Press, Philadelphia, PA.

Pillow, W., 2003, 'Confession, catharsis, or cure? Rethinking the uses of reflexivity as methodological power in qualitative research', International Journal of Qualitative Studies in Education 16(2), 175-196. https://doi.org/10.1080/ 0951839032000060635

Reparando, 2010, Scott Owen Moore, Athentikos, Spring Hill, TN.

Rocke, K. \& Van Dyke, J., 2017, Incarnational training framework: A training guide for developing incarnational leaders engaged in city transformation, Street Psalms Press, Tacoma, WA, viewed 16 March 2018, from http://streetpsalms.org/resources/

Rohr, R., 2004, Soul brothers: Men in the Bible speak to men today, Orbis Books, Maryknoll, NY.

Rohr, R., 2011, Falling upward: A spirituality for the two halves of lives, Jossey-Bass, Hoboken, NJ.

Russell, L., 1993, Church in the round: Feminist interpretation of the Church, Westminster/John Knox Press, Louisville, KY.

Saunders, D., 2010, Arrival city: How the largest migration in history is reshaping our world, Pantheon Books, London, New York.

Soja, E., 2003, 'Writing the city spatially', City 7(3), 269-280. https://doi.org/10.1080/ 1360481032000157478 .

Spees, H., 2012, Notes of the Transformation Networks Consultation, 11-13 September 2012, Nehemiah Center, Managua, Nicaragua.

Street Psalms, 2016, Case Statement 2016-2017: Developing leaders in hard places, Tacoma, WA, viewed 12 March 2018, from http://streetpsalms.org/wp-content/ uploads/2016/06/Street-Psalms-Case-Statement-2016-04-06b-sm.pdf

Street Psalms, 2018, Cities are transformed relationally, Tacoma, WA, viewed 12 March 2018, from http://streetpsalms.org/ourwork/

United Nations Human Settlements Programme (UN-HABITAT), 2003, The challenge of slums: Global report on human settlements 2003, Earthscan Publications Ltd.,
London, Sterling, VA, viewed 11 May 2015, from https://unhabitat.org/books/ the-challenge-of-slums-global-report-on-human-settlements-2003/ 
United Nations Population Fund (UNFPA), 2007, State of the world population 2007: Unleashing the potential of urban growth, UNFPA, New York, viewed 11 May
2015, from http://www.unfpa.org/sites/default/files/pub-pdf/695_filename_ 2015, from http://w

Urban Training Collaborative (UTC), 2014, Concept Paper, 24-27 April 2014, Leadership Foundations, Memphis, TN.

Van Eck, E., 2013, 'When patrons are patrons: A social-scientific and realistic reading of the parable of the Feast (Lk 14:16b-23)', HTS Teologiese Studies/Theological Studies 69(1), Art. \#1375, 14 pages. https://doi.org/10.4102/hts.v69i1.1375

Van Dyke, J. 2008, 'Transforming mission: Challenging the Central American Church to embrace the opportunity of reaching youth in the swelling epidemic of urban street gangs', D.Min., Bakke Graduate University, Dallas, TX.
Vellem, V.S., 2014, 'The task of urban black public theology', HTS Teologiese Studies/ Theological Studies 70(3), Art. \#2728, 6 pages. https://doi.org/10.4102/hts. v70i3.2728

von Balthasar, H.U., 1990, The scandal of the incarnation: Irenaeus against the heresies, transl. by J. Saward, Ignatius Press, San Francisco, CA.

White, H., 1987, The content of the form: Narrative discourse and historical representation, The Johns Hopkins University Press, Baltimore, MD, London.

Witherington III, B., 2015, "Almost thou persuadest me...": The importance of Greco-Roman rhetoric for the understanding of the text and context of the NT', Journal of the Evangelical Theological Society 58(1):63-88. ATLA Religion Database with ATLASerials, Ipswich, MA. 